\title{
EL CONTROL JURISDICCIONAL DE LA DETENCION
}

\author{
Cristián Arias Vicencio*
}

\begin{abstract}
1. Introducción; 2. La audiencia de control de la detención; 3. Justificación del control de la detención: 3.1 La detención como puro ejercicio de fuerza; 3.2 La puesta a disposición del tribunal como garantía de la libertad personal y seguridad individual; 4. Objeto del examen de legalidad de la detención; 5. Actividad de oficio del tribunal; 6. El resultado del examen: La legalidad o ilegalidad procesal penal; 7. La detención imputativa y su control de legalidad; 8. Control de la detención no imputativa; 9. Efectos de la ilegalidad de la detención: 9.1 Efectos respecto del proceso: 9.1.a) Ineficacia del emplazamiento forzado; 9.1.b) Ineficacia del material probatorio; 9.2 Efectos respecto del imputado. La libertad como brecha entre la actuación legal y la ilegal; 9.3 Efectos extra proceso.
\end{abstract}

\section{Introducción}

Con mucha razón se puede sostener que el control jurisdiccional de la detención, en audiencia contradictoria, es uno de los avances más significativos en materia de garantías procesales operados con el cambio de sistema procesal penal en nuestro país ${ }^{1}$.

Sin duda la privación de libertad durante la tramitación del proceso penal es la manifestación más enérgica de la reacción penal estatal y también la más cuestionable, ya que se trata de ejercicio de fuerza previo a una sentencia condenatoria. Este reparo, aplicado a la detención ${ }^{2}$, se hace más evidente cuando hablamos de una detención sin orden judicial ya que será la policía la que deberá decidir sobre la procedencia de esta medida extrema y, en no pocos casos, será el propio ofendido quien privará de libertad a una persona con base en la imputación

\footnotetext{
* Abogado de la Defensoría Penal Pública. Licenciado en Ciencias Jurídicas y Sociales de la Universidad de Chile. Colaborador del Centro de Estudios de la Justicia de la Facultad de Derecho de la Universidad de Chile.

${ }^{1}$ En el Informe Anual sobre Derechos Humanos en Chile 2005, Hechos de 2004, elaborado y publicado por la Facultad de Derecho de la Universidad Diego Portales, se señala que la mayoría de los actores del sistema penal entrevistados coinciden en que uno de los factores principales que ba impactado en la disminución de los abusos a imputados por parte de los agentes de la policia radica en la audiencia de control de la detención (p. 196). Ver también Editorial de la Revista Procesal Penal, No 35, ed. Lexis Nexis, Mayo de 2005.

2 Si bien los cuestionamientos de la doctrina normalmente centran sus críticas en la prisión preventiva o prisión provisional, como antítesis del postulado de la presunción de inocencia, estas mismas críticas no dejan de hacerse extensivas, implícita o explícitamente, también a la detención. Entre las ponencias del Seminario Internacional sobre la materia realizado en Toledo, 2 a 5 de octubre de 1996, se contiene la "Relación de Síntesis", de MARTIN (Ma.T.) que dedica también algunos pasajes a la detención, destacando que la presunción de inocencia que ampara al ciudadano, se hace más evidente frente a la detención, ya que en ese caso no ha mediado intervención del juez. En Prisión Provisional, Detención Preventiva y Derechos Fundamentales, VV.AA., Ediciones de la Universidad de Castilla-La Mancha, Colección Estudios, Cuenca, 1997, p. 268.
} 
Arias - El control jurisdiccional de la detención.

que él mismo sostiene ${ }^{3}$ ejercitando, contra otro ciudadano, una facultad que pareciera pertenecer originariamente al Estado ${ }^{4}$.

Mayor complejidad aún puede adquirir el asunto con otros ingredientes como, por ejemplo, aquellos casos en que esta imputación y ejercicio de fuerza, prácticamente queda entregado a empresas privadas de seguridad o vigilancia las que, hasta cierto punto, actúan por delegación del ofendido, ejerciendo una facultad que también tendría origen en una delegación.

La detención judicial, no obstante que cumple con el requisito de jurisdiccionalidad de las medidas cautelares, pone al juez en una situación en que su control tiene alcances limitados ya que, al resolver sobre su procedencia, se actúa con criterios de urgencia y se dispone de mínimos antecedentes, que son proporcionados por la parte interesada en obtenerla y que la otra no está en situación de controvertir.

De allí la relevancia de un dispositivo de control bien definido. Resultaba indispensable someter a escrutinio del juez la detención en flagrancia, pero también aquella que se materializa por orden del propio juez, lo que se verifica por medio de la audiencia de control de la detención, denominación generalmente aceptada incluso antes de su incorporación explícita en el juicio simplificado- para referirse a la discusión preliminar que tiene lugar en la primera andiencia judicial del detenido que contempla el art. 132 del Código Procesal Penal (CPP) ${ }^{5}$.

\section{La audiencia de control de la detención}

Pese a la importante función que cumple y a la notable incidencia práctica de esta primera audiencia ${ }^{6}$, llama la atención su escasa regulación en el CPP, lo que

\footnotetext{
${ }^{3}$ Como señala MARIN (J.C.), en el nuevo orden procesal penal chileno tratándose de los casos de detención del delincuente sorprendido in fraganti, no bay duda de que la persona que practica directamente la detención (agente de policía o un particular) es quien realiza el correspondiente juicio de imputabilidad, en "Las Medidas Cautelares Personales en el Nuevo Código Procesal Penal Chileno”, Revista de Estudios de la Justicia, No 1, Año 2002, Centro de Estudios de la Justicia, Facultad de Derecho, Universidad de Chile, p. 24.

${ }^{4}$ DE HOYOS (M), La detención por delito, ed. Aranzadi, Pamplona, 1998, p. 77.

${ }^{5}$ En cuanto al uso extendido de esta denominación ver LOPEZ (J.), Derecho Procesal Penal Chileno, T. I (con Horvitz, M.I.), ed. Jurídica de Chile, Santiago, 2002, p. 387. Esta nomenclatura aparece por primera vez en el CPP con la modificación del artículo 393 bis, operada por la Ley $\mathrm{N}^{\circ} 19.789$ de 30 de Enero de 2002, que contempla, para casos de flagrancia, la posibilidad de formular un requerimiento verbal de juicio simplificado, en la audiencia de control de la detención.

${ }^{6}$ Así, DUCE (M.) y RIEGO (C.), describiendo lo que denominan el paradigma estratégico del nuevo proceso penal, parten del supuesto empírico que una amplia mayoría de los casos que llegan a conocimiento del sistema y que tienen altas probabilidades de una persecución exitosa, son aquellos en los cuales existe una simultaneidad, o mucha cercanía temporal, entre los momentos de ocurrencia del hecho, del conocimiento por la policía de haberse cometido un delito, el de la identificación y detención del sospechoso y, finalmente, el del hallazgo o la producción de las pruebas más importantes del caso. Especialmente en los tipos de delitos en que la flagrancia tiene gran incidencia estadística encontrándose normalmente el imputado detenido, el fiscal buscará
} 
contrasta con la reglamentación de otras audiencias, como aquélla sobre solicitud de prisión preventiva u otras medidas cautelares personales.

Así, la audiencia en que se ventila la solicitud de prisión preventiva, encuentra su estructura básica en los arts. 142 y 143 CPP. Las restantes normas del Párrafo $4^{\circ}$, Título $\mathrm{V}$, del Libro Primero la dotan de contenido, fijando con meridiana claridad un objeto de discusión. Las otras medidas cautelares se discuten en audiencia de similar formato, por la remisión del art. 155, inciso final CPP. Su contenido se encuentra principalmente en el art. $155 \mathrm{CPP}$, con remisión a los estándares de procedencia del art. $140 \mathrm{CPP}$ y a las finalidades que se mencionan en el art. 155, inciso primero CPP.

La regulación procedimental de la audiencia de control de la detención, al menos en el art. 132 CPP, es bastante parca. No se señala en esta disposición ni el formato de la audiencia, ni su contenido o posibles temas de discusión, al punto que ni siquiera fluye de su texto que efectivamente deba controlarse la legalidad de la detención, ni cuáles aspectos de legalidad son los que deben o pueden revisarse y, aunque es indiscutible su reconocimiento legal en el art. 393 bis CPP, esta norma tampoco hace referencia a su contenido, dándolo por sobreentendido. Por cierto que estos preceptos deben complementarse con otras disposiciones legales o constitucionales que regulan la detención.

Lo que expresamente reglamenta el art. 132 CPP es la consecuencia procesal de la incomparecencia del fiscal o de su abogado asistente ${ }^{7}$, cuya

mantener su privación de libertad u otras formas de control en la audiencia de formalización de la investigación y planteará la posibilidad de terminar de manera rápida el caso (...). En este tipo de procedimiento por delito flagrante, construido a partir de las necesidades específicas de cada caso, el proceso está, en realidad, centrado en la audiencia de formalización. Este análisis aparece centrado principalmente en los delitos contra la propiedad, los delitos relacionados con el tráfico ilícito de estupefacientes y aquellos relacionados con la ebriedad y conducción de vehículos, que como es sabido, tienen gran incidencia estadística, En Introducción al Nuevo Sistema Procesal Penal, Volumen 1, Universidad Diego Portales, Escuela de Derecho, Santiago, 2002, pp. 346 y ss.

7 La Ley $\mathrm{N}^{\circ}$ 20.074, de 14 de Noviembre de 2005, modificó el inciso primero del art. 132 permitiendo la comparecencia no solo del fiscal a esta audiencia de control de la detención, sino que también la de un "abogado asistente del fiscal". Cabe hacer presente que a este último funcionario no le corresponde realizar en esta primera audiencia ninguna otra actividad procesal que no diga relación con el mero control de la detención. Así quedó sentado en la Sentencia del Tribunal Constitucional que se pronuncia sobre el proyecto, declarando constitucional este precepto, en votación dividida, en el entendido que el inciso segundo del art. 132 CPP no ba sido objeto de modificación alguna (Considerando $14^{\circ}$ ) y que, siguiendo el principio uniforme y reiteradamente aplicado, que consiste en buscar la interpretación de las normas que permita resolver, dentro de lo posible, su conformidad con la Carta Fundamental, se decidirá que el nuevo inciso primero del artículo 132 del Código Procesal Penal, es constitucional en el entendido que "el abogado asistente del fiscal" a que se refiere la norma, debe haber sido contratado como funcionario del Ministerio Público y que no podrá realizar ante los tribunales de justicia otras gestiones o actuaciones que las expresamente establecidas en la ley (Considerando $15^{\circ}$, el destacado es nuestro). Sentencia del Tribunal Constitucional, de 27 de Octubre de 2005, Rol Nº 458. 
Arias - El control jurisdiccional de la detención.

inasistencia determina la inmediata libertad del detenido. También veremos que, en cierto sentido, regula la incomparecencia del defensor.

Entonces, paradójicamente, se ocupa de la ausencia de otros intervinientes sin regular cómo debe procederse respecto de la persona que necesariamente habrá comparecido -en estricto rigor se le habrá forzado a comparecer- y sin cuya presencia la audiencia carecería de objeto: el detenido.

Una primera lectura del art. 132 CPP puede llevar a pensar que no resulta indispensable la presencia del defensor en la audiencia de control. Incluso, su ausencia puede tener como consecuencia la prolongación de la detención. Así expuestas las cosas, la garantía de la defensa técnica se tornaría en contra del imputado, anulando su garantía de la libertad personal ${ }^{8}$.

Una interpretación razonable del precepto, lleva a la conclusión que promover el nombramiento de un defensor de oficio, es carga procesal del fiscal, lo que se deduce del propio texto del art. $132 \mathrm{CPP}$ que contempla la ampliación para el caso que no pudiere procederse de la manera indicada, es decir, cuando sea imposible contar con un defensor, una vez agotados los medios para obtenerlo y no con la mera constatación de su ausencia, casi como si de una consecuencia automática se tratara ${ }^{9}$. Refuerza esta idea lo dispuesto en el art. $102 \mathrm{CPP}$, que impone la carga al fiscal de solicitar el nombramiento de un defensor, lo que deberá tener lugar antes de la realización de la primera audiencia ${ }^{10}$.

En otro orden de ideas y en lo que no existe mayor discusión, aún ante el silencio del art. $132 \mathrm{CPP}$, es que el objeto central de la audiencia de control de la detención, lo constituye el examen de legalidad de la privación de libertad ${ }^{11}$.

\footnotetext{
${ }^{8}$ El problema es que, de prolongarse la detención, la audiencia de control se habrá celebrado sin el defensor, en circunstancias que, de conformidad con lo que disponen los arts. $7^{\circ}$ y $8^{\circ} \mathrm{CPP}$, no se encuentra motivo para sacrificar la garantía de asistencia letrada en esta temprana etapa. Es decir, no existe motivo para sacrificar ninguna de las dos garantías.

${ }^{9}$ En consecuencia, en tales casos, la audiencia se puede suspender por breve lapso, por ejemplo mientras se celebran las restantes audiencias del día, entre tanto se obtiene el nombramiento de un defensor de oficio si no ha existido nombramiento o, en el caso contrario, si se había dado cumplimiento al art. $102 \mathrm{CPP}$, obtener la comparencia de uno distinto del que ha faltado.

10 También la Ley $\mathrm{N}^{\circ}$ 20.074, de 14 de Noviembre de 2005, innova en esta materia. El inciso tercero agregado al art. 131 CPP impone al fiscal la obligación de informar la detención de una persona a su abogado de confianza o a la Defensoría Penal Pública, antes de ponerlo a disposición del tribunal. Al menos si la incomparecencia del defensor dice relación con el incumplimiento de esta obligación, no debiera permitirse la prolongación de la detención fundada en su ausencia. Lo otro que debiera destacarse de esta modificación es que, si bien esta obligación está regulada para los casos de flagrancia, no se divisa motivo para no exigirlo si se trata de una detención judicial. En este último caso bastaría con que el juez que libra la orden imponga esa obligación en su resolución, tal como se viene haciendo en muchos juzgados de garantía sin necesidad de norma expresa.

11 Así, por ejemplo, en CHAHUAN (S.), Manual del Nuevo Procedimiento Penal, $2^{a}$ edición, ed. Lexis Nexis, Santiago, 2002, p. 230, se afirma sin vacilaciones que la denominación de esta primera
} 
Algunos señalan que es el art. $95 \mathrm{CPP}$ el que dota de contendido y finalidad a esta primera audiencia, esto es, el examen de la legalidad de la detención ${ }^{12}$, ya que en ese precepto encontramos expresamente la posibilidad de examinar o impugnar la legalidad de la privación de libertad.

No existe el mismo consenso a la hora de definir el objeto de ese control y cuáles son los efectos procesales en caso que se detecten defectos legales ${ }^{13}$.

Como se ve, pese a su instalación como novedoso instituto procesal del sistema de persecución penal, el control de la detención en audiencia sigue planteando algunas interrogantes, por lo que pretendemos aproximarnos al panorama de la cuestión e intentar develar cuáles son las instituciones asociadas a los problemas de frecuente ocurrencia, más que concentrarnos en las respuestas específicas que se pudieran ensayar, sin perjuicio que en algunas ocasiones tomaremos partido ${ }^{14}$.

audiencia obedece precisamente a su objeto, es decir que en ella se controla la legalidad de la detención (destacado del original).

12 Así para RIEGO (C.) y DUCE (M.), en "La etapa de investigación en el nuevo proceso penal”, p. 110, en Nuevo Proceso Penal, VV. AA., ed. Conosur Ltda., Santiago, 2000, pareciera ser que es en el artículo 95 donde encontramos el fundamento del control de legalidad de la detención y, por lo tanto, sería este precepto el que dotaría de contenido general a esta audiencia. Para BLANCO (R.), DECAP (M.), MORENO (L.) y ROJAS (H.), en Litigación Estratégica en el Nuevo Proceso Penal, ed. Lexis Nexis, Santiago, 2005, p. 47, el artículo 95, dotaría de contenido específico a esta audiencia, para controlar la eventual existencia de apremios contra el imputado. No parece ser el caso de LOPEZ (J.), cit., p.387 y ss., que considera el control de las condiciones de la detención por dos vías diversas: la audiencia de control de la detención y el amparo ante el juez. de garantía, aunque no las declara expresamente incompatibles.

${ }^{13}$ Sobre las diferencias, por ejemplo, en Litigación Estratégica..., cit., pp. 43 y ss. si bien estos varios autores proponen de manera común un formato de audiencia y listado de temas, no hay tal comunidad de ideas respecto de los efectos de la declaración de ilegalidad de la detención. Así sólo para MORENO (L.) y ROJAS (H.), la declaración de ilegalidad podría tener como consecuencia la libertad inmediata del detenido en ciertos eventos como, la ausencia de una hipótesis de flagrancia o el incumplimiento del plazo máximo de detención. A su turno, sólo para BLANCO (R.) la declaración de ilegalidad no obsta para ampliar la detención, sin restricciones, en cambio para los otros, se eleva el umbral de exigencia para decretar esa ampliación.

${ }^{14}$ En la búsqueda de respuestas -en cierto sentido disociadas de las instituciones que explican la detención- el ejemplo más evidente de soluciones muy divergentes, es la discusión en torno a si la declaración de ilegalidad de la detención produce o no la liberación inmediata del imputado, quedando en este último caso sólo la posibilidad de citarlo a una audiencia en fecha próxima (art. 231 $\mathrm{CPP}$ ). En este debate, la toma de posición constituye una verdadera lucha inconciliable por dos principios sin punto medio, algo así como eficientismo v/s garantismo, en circunstancias que pareciera ser que antes de decidir por uno u otro camino hay que partir por preguntarse cuál es el significado procesal que tiene la detención, cuál es el significado que le asigna el ordenamiento jurídico a los sistemas de control y cuál el que debería tener la ilegalidad en materia procesal. 
Arias - El control jurisdiccional de la detención.

\section{Justificación del control de la detención}

Como es evidente, el control jurisdiccional de la detención encuentra su fundamento inmediato en la creación de la nueva institucionalidad procesal penal, que contempla la instancia judicial para el control de todas las actividades de la investigación. Este control se ha entregado al juez de garantía, a quien se le asigna la función de resolver todos los conflictos que puedan presentarse entre la actividad de investigación del fiscal y los derechos e intereses del imputado y los demás intervinientes ${ }^{15}$.

Existe un fundamento constitucional para este control, que es el resguardo de la libertad personal y seguridad individual. Esta garantía constitucional cobra especial importancia como objeto de protección, cuando es el proceso penal el que puede llegar a suprimirla, siendo particularmente crítico el ejercicio de pura fuerza que una detención normalmente supone.

Para explicar el fundamento del control de la detención con base en la protección de este derecho fundamental, desarrollaremos dos ideas básicas. Por una parte destacaremos la evidente dimensión fáctica que tiene la detención, como puro ejercicio de fuerza y, por la otra, destacaremos su dimensión jurídica, como poder sometido a control, precisamente para garantizar la libertad personal y la seguridad individual.

\subsection{La detención como puro ejercicio de fuerza}

Bajo el concepto de detención puede quedar comprendido un conjunto de medidas de fuerza de carácter bien dispar, de orígenes, características y finalidades a veces disímiles. Pensemos en una detención dispuesta por autoridad no judicial ${ }^{16}$, en comparación con la detención ordenada por el juez o, en esta última, comparada con la que practica la policía en caso de flagrancia. Pareciera ser que el único común denominador es lo efímero y preliminar de estas medidas de fuerza ${ }^{17}$.

Por otra parte, no resulta infrecuente el uso de etiquetamientos erróneos de ciertas privaciones de libertad que se presentan como realidades jurídicas pretendidamente diferenciadas de la detención. Así ha ocurrido tradicionalmente con el concepto de retención para describir privaciones de libertad practicadas por la policía que no encuentran un fundamento legal muy preciso o para explicar las privaciones de libertad de inimputables por razón de su edad.

\footnotetext{
${ }^{15}$ Mensaje del Ejecutivo del Proyecto de Código Procesal Penal Chileno.

${ }^{16} \mathrm{La}$ Constitución contempla en el art. $19 \mathrm{~N}^{\circ} 7$, letra c) la detención por autoridad, es decir, por funcionario público distinto que el juez. No es una posibilidad que haya previsto el Código Procesal Penal.

17 Para efectos de delimitar el objeto de este trabajo, por cierto que cuando hablamos del control jurisdiccional de la detención, nos estamos refiriendo exclusivamente a la detención por razón del proceso penal.
} 
Este uso no parece ajeno a nuestro CPP, si observamos una de las hipótesis descritas por el art. 85, que el legislador denomina conducción a la unidad policial, en circunstancias que se trata de una auténtica detención ${ }^{18}$.

De allí que entre nosotros ${ }^{19}$ tenga cabida la idea de adoptar un concepto amplio de detención, comprensivo de toda privación de libertad ambulatoria que no sea prisión preventiva o ejecución de pena, invocando un fin previsto y permitido por el ordenamiento jurídico ${ }^{20}$.

La incorporación de un concepto amplio de detención permite reconocer como tal al resultado material, físico o puramente fáctico en la esfera de libertad de una persona, respecto de quien se puede decir que en la realidad de las cosas, está efectivamente privada de ella, con independencia del nombre con el cual se le denomine ${ }^{21}$.

Por cierto que lo relevante no es sólo identificar como auténticas detenciones a estas privaciones de libertad, sino que deberíamos reconocer concurrentes a su respecto las garantías normalmente asociadas a la detención ${ }^{22}$ y las consecuencias jurídicas que ello trae aparejado ${ }^{23}$, como por ejemplo, como cuestión básica, su control jurisdiccional.

${ }^{18}$ LOPEZ (J.), cit., pp. 380 y ss. denomina derechamente detención para fines de identificación a esta conducción. En similar sentido CISTERNA (A.), La detención por flagrancia en el nuevo proceso penal, Doctrina- Jurisprudencia, Librotecnia, Santiago, 2004, pp. 117 y ss. En España es la forma común de denominar a esta facultad contemplada en el art. 20 de la Ley de Seguridad Ciudadana, DE HOYOS (M.), cit., pp. 233 y ss. ; QUERALT (J.), La asistencia letrada al detenido, Colección Atelier Penal, Barcelona, $3^{\text {a }}$ edición, 1999, pp. 38 y ss.).

${ }^{19}$ Ver LOPEZ (J.), cit., pp. 362 y ss.

${ }^{20}$ LOPEZ (J), cit., p. 363, con cita de GIMENO SENDRA.

${ }^{21} \mathrm{La}$ doctrina española ha destacado suficientemente este punto. Muy citada es la sentencia del Tribunal Constitucional Español, 98/1986, de 10 de Junio que señala: Debe considerarse como detención cualquier situación en que la persona se vea impedida u obstaculizada para autodeterminar, por obra de su voluntad, una conducta licita, de suerte que la detención no es una decisión que se adopte en el curso de un procedimiento, sino una pura situación fáctica, sin que puedan encontrarse zonas intermedias entre la detención y la libertad (Ver cita de MORENO CATENA, en LOPEZ (J.), cit., p. 363; ver también DE HOYOS (M.), cit., p. 22.). Del mismo modo se dice que detener es una pura situación fáctica que tiene lugar siempre que a una persona se le impide realizar una conducta que voluntariamente desarrollaria de no existir una coacción exterior que se lo imposibilita. CLIMENT (C.), Las detenciones ilegales policiales, ed. Tirant lo Blanch, Valencia, 1998, p. 68, con cita de BANACLOCHE.

22 GIMENO (V.), Derecho Procesal Penal, ed. Colex, Madrid, 1ª edición, 2004, p. 495, con apoyo en sentencias del Tribunal Constitucional Español y del Tribunal Supremo Español.

${ }^{23}$ En CISTERNA (A.), cit., p. 118, encontramos una consecuencia importante. Al reconocer en el "control de identidad" una forma de privación de libertad que hace excepción a la detención por orden, su constitucionalidad se hace cuestionable ya que sólo la detención por flagrancia está concebida como excepción constitucional a la detención ordenada por el juez o la autoridad (con cita de HORVITZ). 
Arias - El control jurisdiccional de la detención.

Nuestro punto de partida es, precisamente, que el evento generador del control jurisdiccional, debe necesariamente entenderse como detención en un amplio sentido, comprensivo de toda privación de libertad, independientemente de su causa o de la forma que adopte, precisamente por el componente puramente fáctico que toda detención conlleva.

Esta afirmación también resulta válida para la detención ordenada por un juez porque, aún siendo adoptada desde el estrado, en definitiva se materializa por medio de una determinada conducta de los agentes estatales encargados de practicarla.

El control se justifica en todo tipo de detenciones, no sólo por el componente puramente fáctico que una captura tiene sino que, también, porque el examen de legalidad tendrá como primera meta el proceso de subsunción, vale decir, la definición previa si la situación de hecho que se plantea, el núcleo fáctico, por ejemplo la flagrancia, corresponde o no a una situación efectivamente permitida u ordenada por el ordenamiento jurídico, o eventualmente prohibida.

En definitiva, se trata de resolver en sede jurisdiccional si el "fin previsto y permitido" que se invoca es o no efectivo. Si hablamos de control jurisdiccional de la detención, no se puede partir de una definición apriorística de su concepto, porque entonces quedaría entregado a quien la practica si se controla o no, así como los límites de ese control y las consecuencias que -en caso de infracción- trae aparejado este ejercicio de fuerza.

\subsection{La puesta a disposición del tribunal como garantía de la libertad personal y seguridad individual}

Con la detención se anula por completo la libertad personal, es decir, por muy reducida que sea su duración, no se puede hablar de una mera perturbación, restricción o limitación de esta garantía constitucional. La libertad ambulatoria no se perturba, restringe o limita, ya que, por sus características, no es un derecho que admita situaciones intermedias; o puede el sujeto alejarse del lugar en que no desea permanecer, o no puede hacerlo ${ }^{24}$.

Pero no solo la libertad ambulatoria está en juego cuando se detiene a una persona, también lo está la seguridad individual, tal como se reconoce en el art. $19 \mathrm{~N}^{\circ}$ 7 de la Constitución ${ }^{25}$. La seguridad individual, como derecho asegurado

\footnotetext{
${ }^{24}$ DE HOYOS (M.), cit., p. 22.

25 La afectación mediante una detención ilegal de la seguridad individual, como un plus de la afectación de la libertad personal, queda de manifiesto en una prevención de los Ministros Sres. Alberto Chaigneau del Campo y Milton Juica Arancibia, en Sentencia de Corte Suprema confirmatoria de una acción de amparo acogida por la Corte de Apelaciones de Coyhaique, en contra de una orden de detención librada verbalmente. Los previnientes tuvieron presente para acoger el amparo que, tratándose de la garantía constitucional de la libertad personal se aplica preferentemente el
} 
constitucionalmente, se estructura en binomio con la libertad personal, puesto que ambas garantías aparecen indisolublemente relacionadas con la persecución penal $^{26}$, porque es evidente que mientras la persona está privada de libertad es más vulnerable como sujeto pasivo del proceso que estando en libertad.

Para nadie es un misterio que durante la detención inicial, esa vulnerabilidad dice relación con el peligro de aplicación de tormentos y en general de métodos ilícitos para obtener la primera versión de los hechos y de primera fuente, es decir, del propio imputado ${ }^{27}$. El riesgo de conductas estatales ilícitas se incrementa con el imputado vinculado corporalmente con el Estado persecutor, mas bien que jurídicamente, sin contar con que, además, el estado inicial de la privación de libertad tiene por si sólo un carácter aflictivo ${ }^{28}$.

Para neutralizar esta vulnerabilidad, el Estado reglamenta un conjunto de prohibiciones $^{29}$ y obligaciones ${ }^{30}$ a fin de generar un escenario de seguridad individual ${ }^{11}$

artículo 5 del Código Procesal Penal, en cuanto dispone que no se podrá aplicar ninguna forma de privación o restricción de libertad a ninguna persona, sino en los casos y en la forma señalada por la Constitución y las leyes, añadiendo dicho precepto que las disposiciones que autorizan la restricción de la libertad serán interpretadas restrictivamente y no se podrán aplicar por analogía y, agregan, que del contexto del artículo $19 \mathrm{~N}^{\circ} 7$ letra c) de la Constitución Política de la República y de los artículos 94 letra a), 125 y 154 del Código Procesal Penal, fluye claramente que, tratándose de este esencial derecho, la orden de detención debe siempre disponerse por escrito a fin que el imputado realmente se sienta intimado legalmente de la medida coercitiva que se le está imponiendo, puesto que entender lo contrario, aparte que el derecho básico de la misma libertad personal se encuentra amenazado con la interpretación extensiva del artículo 9 del citado código, se produce de inmediato el quebrantamiento de la segunda garantía del derecho cual es la seguridad personal de quien o quienes sin contar con una orden concreta y determinada de su detención, deben soportar además junto a su entorno, una situación de incertidumbre que a este nivel no acepta la norma constitucional referida precedentemente ya que lo que asegura el Estatuto Fundamental es el derecho a la libertad personal y la seguridad individual. (Sentencia Rol N 3716-03, de 9 de Septiembre de 2003).

26 Sin duda que la libertad personal, como derecho subjetivo asegurado en la Constitución, tiene connotaciones que exceden su relación con el proceso penal. Sin embargo, son precisamente los permanentes riesgos que genera la actividad de persecución penal lo que acaparó las mayores preocupaciones del constituyente. Por eso, entre otros motivos, se explica la consagración de la libertad personal en binomio con la seguridad individual y por eso el catálogo de consecuencias asociadas que enumera el constituyente en el art. $19 \mathrm{~N}^{\circ} 7$, particularmente la regla nacional del nemo tenetur, dicen principal relación con los resguardos en el proceso penal. Ver historia del establecimiento de este precepto en EVANS (E.), Los Derechos Constitucionales, T II, $2^{\text {a }}$ edición actualizada, ed. Jurídica, Santiago, 1999, pp. 174 y ss.

27 Como es sabido, en los orígenes del proceso penal inquisitivo, la prisión provisional -por extensión la detención- se asocia a una mejor posibilidad para aplicar tormentos en búsqueda de la confesión. Como explica ANDRES IBAÑEZ (P.), una larga evolución histórica que es el pensamiento ilustrado y la de la construcción de la propia categoría constitucional de la libertad llevó a la abolición formal de la tortura en la experiencia procesal y, así, a la disociación asimismo formal de la tortura y la prisión provisional. En Prisión Provisional, Detención Preventiva y Derechos Fundamentales, VV.AA., cit., p.17

${ }^{28}$ Se dice que pocas situaciones resultan más intimidantes, al paso que representan con mayor fuerza el poder del Estado persecutor, que la privación de la libertad ambulatoria de los sujetos, sea en virtud de una orden judicial, sea por encontrarse el sujeto en situación de flagrancia. TAVOLARI (R.), Instituciones del nuevo proceso penal. Cuestiones y casos, ed. Jurídica, Santiago, 2005, p. 281.

${ }^{29}$ Sin duda la más trascendente es la prohibición de tortura y en general de malos tratamientos. 
Arias - El control jurisdiccional de la detención.

para el sometido a detención. Este escenario se puede traducir, en términos procesales, como la incoercibilidad del imputado, entendida como la prohibición general de no utilizarlo como fuente de información ${ }^{32}$.

Entonces, si por una parte el Estado se impone un deber de abstención, consistente en no privar a nadie de libertad sino en los casos y en la forma señalados en la Constitución y las leyes y, si por la otra, reglamenta un escenario de incoercibilidad del individuo sometido a detención, debe existir, como contrapartida, un deber de verificar si esa privación de libertad ha tenido lugar o no conforme a la legalidad, para que todos los resguardos de la libertad personal y seguridad individual no resulten puras declaraciones programáticas.

De allí que se establezca en el art. $19 \mathrm{~N}^{\circ} 7$, letra c) de la Constitución, que la detención por flagrancia o por orden de autoridad generan la obligación de poner al detenido a disposición del juez competente.

El Código Procesal Penal, perfeccionando esta garantía, contempla diversas disposiciones en el mismo sentido. Así, el art. 94 letra c) consagra a favor del imputado la garantía de ser conducido sin demora ante el tribunal que bubiere ordenado su detención.

El art. 95 CPP establece que la privación de libertad dispuesta por resolución judicial sólo puede impugnarse por los medios procesales que correspondan y ante el mismo tribunal que la dictó. No existe otro medio procesal más propio que la audiencia de control de la detención. Será ésta la que tendrá como objeto fundamental examinar la legalidad de la detención tal como lo indica el propio texto de este precepto.

En lo que toca a la detención en flagrancia corresponde revisar su legalidad conforme con el inciso primero del art. 95 CPP. Esta disposición contempla también la conducción sin demora del detenido ante un juez de garantía consagrando un auténtico babeas corpus ${ }^{33}$ para todo tipo de privación de libertad, que tiene entre sus objetivos el examen de legalidad y, en todo caso, de las condiciones en que el amparado se encontrare, es decir la revisión de la ejecución o materialización de la detención.

\footnotetext{
30 Por ejemplo la obligación de informar el motivo de la detención o la de librar órdenes de detención por escrito. Aunque, sobre esta última exigencia, la Ley $\mathrm{N}^{\circ} 20.074$ de 14 de Noviembre de 2005, ha relativizado esta formalidad, en casos de urgencia.

${ }^{31}$ DUCE (R.) y RIEGO (C.), señalan que la regulación de la detención consiste en el establecimiento de un catálogo de derechos del detenido orientados a proteger su seguridad e integridad física, asi como a permitirle el ejercicio del derecho a defensa, que se reconoce claramente desde esta temprana etapa. En "La etapa de investigación...", cit., p.108.

${ }^{32}$ HORVITZ (Mª I.), Derecho Procesal Penal Chileno, (con López, J.), ed. Jurídica de Chile, Santiago, 2002, t. I, p. 234.

${ }^{33}$ DUCE (R.) y RIEGO (C.), “La etapa de investigación...”, cit., p.110.
} 
Finalmente y aunque escasamente citados a efectos de fundamentar la obligación examinar la legalidad de la detención, encontramos los artículos 9.3 y 9.4 del Pacto Internacional de Derechos Civiles y Políticos (PIDCP) ${ }^{34}$ y 7.5 y 7.6 de la Convención Americana sobre Derechos Humanos (CADH) o "Pacto de San José de Costa Rica" 35 , que contemplan la garantía de toda persona retenida, detenida o presa de ser llevada sin demora ante un juez y la garantía del detenido, preso o privado de libertad para recurrir a un juez que decida a la brevedad posible, sin demora, sobre la legalidad de su privación de libertad, con cláusula expresa de orden de libertad en caso que la detención fuere ilegal.

\section{Objeto del examen de legalidad de la detención}

Los aspectos concretos de revisión aparecen en todo el ordenamiento jurídico y probablemente enumerarlos sería efectuar un catálogo interminable. Además supondría una consideración no solo de las normas generales sobre privación de libertad, sino que también de las leyes especiales que en algunos casos perfeccionan el catálogo de derechos y garantías del detenido o, en otros, dentro del marco de la Constitución, los restringen.

Solo centrándonos en las disposiciones del CPP, habrá que principiar por el art. 122, desde luego repasando los arts. 125 a 138, que regulan los casos, forma y plazos de la detención, incluyendo el art. 151, sobre prohibición de comunicaciones. También los arts. 93 a 98 sobre derechos y garantías del imputado, especialmente del privado de libertad. Este análisis sería insuficiente si no se repasaran las normas que regulan aquello que está ordenado, prohibido o permitido a la policía, especialmente las limitaciones a sus actividades autónomas, como el control de identidad, la detención para fines de identificación y la declaración del imputado ante la policía, especialmente los arts. 85, 86 y 91. Además habrá que repasar las normas que regulan la investigación no judicializada especialmente los arts. 182, 193 y 195, este último sobre métodos prohibidos, así como también los arts. 196, 197, 203, entre otros. Finalmente, dentro de los principios generales, cobran especial relevancia los arts. $4^{\circ}, 5^{\circ}, 7^{\circ}, 8^{\circ}$ y $9^{\circ}$, sin pretender con esto cerrar la numeración.

\footnotetext{
34 Art. 9.3. PIDCP.- Toda persona detenida o presa a causa de una infracción penal será llevada sin demora ante un juez. u otro funcionario autorizado por la ley para ejercer funciones judiciales, y tendrá derecho a ser juzgada dentro de un plazo razonable o a ser puesta en libertad. La prisión preventiva de las personas que hayan de ser juzgadas no debe ser la regla general, pero su libertad podrá estar subordinada a garantías que aseguren la comparecencia del acusado en el acto del juicio, o en cualquier otro momento de las diligencias procesales y, en su caso, para la ejecución del fallo. Art. 9.4. PIDCP.-Toda persona que sea privada de libertad en virtud de detención o prisión tendrá derecho a recurrir ante un tribunal, a fin que éste decida a la brevedad posible sobre la legalidad de su prisión y ordene su libertad si la prisión fuere ilegal.

35 ser privada de su libertad tiene derecho a recurrir a un juezo tribunal competente a fin que éste decida sobre la legalidad de tal amenaza, dicho recurso no puede ser restringido ni abolido. Los recursos podrán interponerse por sí o por otra persona.
} 
Arias - El control jurisdiccional de la detención.

Para una adecuada sistematización de los aspectos de legalidad se puede recurrir a diversos métodos y cada uno dependerá de la perspectiva con que se adopte el sistema. Lo relevante es que se aborden todas las variables posibles y que la sistematización sirva de guía o pauta de trabajo ${ }^{36}$.

A partir de lo que dispone el art. $19 \mathrm{~N}^{\circ} 7$ letra b) de la Constitución que señala que nadie puede ser privado de su libertad personal ni esta restringida sino en los casos y en la forma determinados por la Constitución y las leyes, podemos establecer una pauta general para el examen de legalidad de la detención, con base en la formulación constitucional de esta garantía.

Así, podemos hablar de legalidad material, si el análisis se orienta a la verificación de la existencia de un caso previsto en la constitución o en la ley, o de legalidad formal, si la verificación se orienta a controlar el cumplimiento de las formas que la constitución y las leyes establecen para ese caso.

Pero esta clasificación puede ser complementada desde otra óptica. Es claro que la detención constituye un procedimiento y no un acto, es decir, la detención es un proceso dinámico y no una situación estática, de tal manera que su materialización no se produce en un instante, sino que se sucede en el tiempo. Por definición la detención es privación de libertad de corta duración, a la cual se le pone término una vez que ha comparecido el detenido al acto del procedimiento que motivó la medida ${ }^{37}$.

Por otra parte, tanto las formalidades que la resguardan, como las prohibiciones y obligaciones que asume el Estado para generar un escenario de incoercibilidad, no sólo se refieren al momento en que se inicia la detención, sino que se aplican durante toda su ejecución ${ }^{38}$.

\footnotetext{
36 BRUZZONE (G.), propone cinco momentos de reflexión cada vez que se utilice una medida de coerción o de injerencia, sea para fundar su aplicación, para criticar sus supuestos de aplicación o para controlarlas, lo que se plantea como un verdadero método o programa de trabajo para la praxis, el que nos parece igualmente útil para el control de la detención y que es el siguiente: 1) nulla coactio sine lege (no hay medida de coerción sin ley); 2) competencia del órgano que dispone la medida; 3) necesidad de la medida; 4) idoneidad de la medida; y 5) proporcionalidad de la medida. La nulla coactio sine lege como pauta de trabajo en materia de medidas de coerción en el proceso penal, Estudios sobre Justicia Penal, Homenaje al Profesor Julio B. J. Maier, Editores del Puerto, Buenos Aires, 2005, pp. 243 y ss.

${ }^{37}$ LOPEZ (J.), cit., p. 382.

${ }^{38}$ En TAVOLARI (R.), Habeas Corpus, Recurso de Amparo, ed. Jurídica de Chile, Santiago, 1995, pp. 165 y ss., encontramos una clasificación de las formalidades que acompañan a las decisiones que privan de libertad (y que) han de verificarse en etapas diferentes de la ejecución del decreto respectivo (...) como sigue: 1) Formalidades anteriores a la ejecución de la orden; 2) Formalidades coetáneas con la ejecución, y 3) Formalidades posteriores a la ejecución. Esta clasificación pareciera entender que la ejecución de la detención se agota con la captura misma del detenido ya que considera como formalidades posteriores a la ejecución de la orden los requisitos que tiene la conducción del detenido al lugar en que se hará efectiva su privación de libertad y ciertas obligaciones que tiene el encargado del lugar del detención. Sin embargo, esta aparente diferencia con lo que estamos planteando es una pura cuestión de nomenclaturas ya que,
} 
De allí que podamos señalar que tanto la legalidad material como la legalidad formal, se pueden analizar, tanto en el origen como en el transcurso de la detención, dando lugar a otra clasificación que consiste en legalidad de origen y legalidad de la ejecución.

Con todo lo discutible que puedan ser estas categorías y con todo lo arbitrario que tiene toda clasificación, solo se ha pretendido destacar dos puntos. En primer lugar, que el examen de legalidad no se puede agotar en el análisis del origen de la detención, sino que también es preciso poner atención a su ejecución. En segundo lugar, que los rubros de ilegalidad son muy variables y que, por lo mismo, no toda ilegalidad puede tener la misma consecuencia ni la misma valoración. Así, por ejemplo, si no estamos frente a un caso en que la Constitución o la ley autorizan la detención, pareciera ser que ésta debería hacerse cesar de inmediato. Si no se ha cumplido una forma habrá que ponderar la finalidad perseguida con su establecimiento y cómo afecta su incumplimiento la libertad personal o la seguridad individual para tomar una decisión sobre sus efectos.

\section{Actividad de oficio del tribunal}

En cuanto a la actividad del tribunal, consideramos que tiene amplias facultades para controlar la detención y no se divisa motivo alguno para que se inhiba de realizar actividades de oficio.

Como hemos señalado, es el Estado el que se ha impuesto el deber de abstención y es el mismo, a través de sus jueces, quien debe velar por el cumplimiento de los mandatos y prohibiciones que rodean el proceso de detención.

La presencia del defensor no es la garantía de la libertad personal, sino que solo garantía de la defensa técnica. Por ello pareciera ser que el control no puede quedar entregado solo a las partes. La garantía de la libertad personal y seguridad individual es la puesta a disposición del tribunal la que no tendría ningún sentido si el tribunal estuviera inhibido de actuaciones de oficio ${ }^{39}$.

sea que se estime como parte de la ejecución de la detención lo que ocurre entre la captura y la puesta a disposición, o que se estime como algo posterior a la ejecución, lo cierto es que igualmente se encuentra rodeado de formalidades que deben cumplirse.

${ }^{39}$ En audiencia RIT N 95-2004, 15/03/04, Juzgado de Garantía (J.G.) de San Pedro de la Paz, sin existir debate entre los intervinientes sobre legalidad de la detención y luego que el fiscal expone las circunstancias de la detención, el juez pregunta con mayor detalle sobre el punto, declarando finalmente que la detención es ilegal. En lo pertinente señala: Que la defensa no ha hecho cuestión respecto de la legalidad de la detención. Sin perjuicio el Control de la Legalidad de la Detención se impone como una actividad propia del Juez de Garantía, atendido lo que dispone el art. 95 del Código Procesal Penal, en relación del artículo 393 bis que le da nombre a esta audiencia. Citada por CISTERNA (A.), cit., pp. 182 y ss. 
Arias - El control jurisdiccional de la detención.

De cualquier manera el art. $10 \mathrm{CPP}$ autoriza para cautelar garantías, actuando de oficio. Es ya casi un lugar común asilarse en este precepto con fines tutelares de garantías, disposición que puede ser complementada por el art. 14 letra a) del Código Orgánico de Tribunales (COT), para justificar esta actividad jurisdiccional $^{40}$.

Por no estar contemplado en el art. $10 \mathrm{CPP}$, resultan menos evidentes las facultades de oficio de un tribunal oral para actuar en cautela de la libertad personal y seguridad individual del detenido puesto a su disposición. Por supuesto que los casos de flagrancia quedan fuera de sus posibilidades de intervención ${ }^{41}$ por lo cual el asunto se circunscribe al control de sus propias órdenes de detención para asegurar comparecencia al juicio oral.

En estos casos se puede acudir a la idea de la puesta a disposición del tribunal, como garantía que cobra sentido en la medida que exista una real verificación de la legalidad de la detención, por parte de ese tribunal que la decreta, al cual le corresponde el control según lo disponen los arts. 94 letra c), 95 inciso tercero y 131, inciso primero $\mathrm{CPP}^{42}$. Como la garantía no solo consiste en la facultad de recurrir ante el tribunal, sino que en ser derechamente puesto a su disposición, la pasividad de los intervinientes puede resultar irrelevante.

No obstante lo dicho, el art. 18, letra d) COT, en relación con los tres artículos previamente citados, resulta lo suficientemente amplio como para decidir a favor de las facultades oficiosas del tribunal que ha expedido la orden y, especialmente, puede deducirse del art. $97 \mathrm{CPP}$, que se refiere a la obligación del tribunal -en este caso del tribunal que ha dispuesto la orden- conforme al avance del procedimiento, del cumplimiento de las normas legales que establecen derechos y garantías del imputado. Es decir, siempre existe obligación de verificar la legalidad de la detención, cualquiera sea la etapa del procedimiento en que se produzca.

\footnotetext{
40 LOPEZ (J.), cit., p. 387, señala que la audiencia de control de la detención debiera iniciarse con la verificación, de oficio, por parte del juez de garantía, de que se ha dado cumplimiento al deber de información de derechos al detenido (art. 136 CPP) y de que se han respetado las normas legales que establecen sus derechos y garantías, dejando constancia en los respectivos registros (art. 97).

${ }^{41}$ Salvo que se tratara de la situación excepcional del art. 128 CPP pero aún así, el control debería hacerlo, en definitiva, un juez de garantía.

${ }^{42}$ La Ley N² 20.074 de 14 de Noviembre de 2005, modifica el art. 70 CPP en el sentido de facultar al juez de garantía del lugar donde se practica la detención para controlarla. Parece discutible que esta nueva disposición sea aplicable a las detenciones libradas por un tribunal oral, pero aún siéndolo, esta regla, que transfiere competencia, no elimina la función de control, sino que la radicaría en otro tribunal por razones de celeridad y distancia.
} 


\section{El resultado del examen: La legalidad o ilegalidad procesal penal}

El examen de legalidad de la detención puede producir reparos cuya constatación judicial determina la existencia de una detención ilegal. Sin embargo, es preciso detenerse en el concepto que estamos usando al referirnos a una detención ilegal por la evidente cercanía que tiene con las detenciones ilegales constitutivas de delito.

Así, se ha dicho que la detención en flagrancia posee la naturaleza jurídica de un "acto procesal con función doble" pues, además de cumplir fines de derecho procesal, constituye también una causa de justificación en relación con la posible comisión del delito de detención ilegal ${ }^{43}$. Del mismo modo, entre nosotros, se considera entre los casos generalmente propuestos de causal de justificación, aquellos ejecutados en cumplimiento de un deber resultante de funciones públicas y, particularmente, cuando los agentes de la autoridad emplean medios coercitivos, como la detención en casos de flagrancia por un agente de la policía ${ }^{44}$.

Como se ve, pareciera ser usual considerar la detención por razón del proceso penal, no como una acción en principio atípica, sino que en principio justificada. Se tiende a ver la detención que es declarada ilegal en relación con el delito como si se tratara de una cara y un reverso perfectamente equivalentes. Si se ha declarado una detención ilegal, entonces habrá existido una acción típicamente antijurídica; si se declarado una detención legal, entonces el particular o el agente que la practicaron, habrán incurrido en una acción típica pero justificada.

Es preciso entonces, manejar un concepto procesal penal de la detención ilegal, bien diferenciado del concepto sustantivo penal. El enfoque penal o punitivo de la constatación de una ilegalidad en la detención, aventuramos, ha producido, especialmente al inicio de la reforma en cada región, una cierta inhibición de los jueces para declarar la ilegalidad de la detención ${ }^{45}$. Incluso, para

\footnotetext{
${ }^{43}$ DE HOYOS (M.), cit., p.96.

${ }^{44}$ Texto y comentario del Código Penal Chileno, VV.AA., ed. Jurídica, Santiago, 2002, p. 154.

45 Ejemplo de ello es la siguiente audiencia de control de la detención: La defensa, discutiendo las hipótesis de flagrancia, solicita que se declare ilegal la detención, que se ponga en inmediata libertad a (su) representado y, por el momento se reserva la acción legal porque (a su juicio) estariamos dentro de lo establecido en el artículo 148 del Código Penal. El tribunal señala, entre otros reparos, que no está la situación de hecho producida en la detención del Sr. Imputado en el caso de la letra b) del artículo 130 del Código Procesal Penal y, en consecuencia, solo cabe determinar, que la detención se practicó por Carabineros de Chile sin cumplir con los requisitos legales, que exigen para esta situación la autorización previa de este Juez de Garantía, para proceder a esta medida cautelar de tanta entidad (...). Por lo tanto y teniendo presente lo ordenado pro el artículo $7^{\circ}$ de nuestra Constitución Política, y teniendo también en consideración que acceder a la solicitud del Sr. Defensor, significa estar dando por cierto un hecho para el cual no se le ha atribuido competencia en ninguna norma del Código Procesal Penal, esto es, declarar ilegal la detención, de modo formal, como el lo solicita, hemos de recordar que toda magistratura debe obrar dentro de la órbita que se ha puesto dentro de su competencia (...) por ello se limitará a declarar que en la detención de DGZB ejecutada a las 11:15 del día 26 de Enero del año 2004, en Isla de Pascua, no se ha guardado por Carabineros de Chile, por los funcionarios que intervinieron, con las formalidades legales,
} 
Arias - El control jurisdiccional de la detención.

eludir la denominación, se recurre a eufemismos como "vulneración del Estatuto del Detenido", "detención no ajustada a derecho" o equivalentes, en circunstancias que lo relevante no es la rotulación, sino que las consecuencias que asociamos a esa constatación.

Así como nadie podría sostener que al acoger una acción constitucional de amparo, por haberse constatado una infracción legal o constitucional, es decir, al dar por cierto que ha existido una detención ilegal, ello significa la constatación de un delito, en sede del control de la detención tampoco debería hacerse esta equivalencia. Quizás la novedad del control de la detención ha generado tanto entusiasmo como confusión.

\section{La detención imputativa y su control de legalidad}

En términos generales, la detención imputativa se define como aquella que se decreta o practica sin citación previa, con el objeto de asegurar la presencia del imputado a la audiencia en que se pretende formalizar la investigación y, eventualmente, adoptar alguna medida cautelar personal de mayor intensidad en su contra ${ }^{46}$.

Por extensión, atento lo que dispone el artículo 393 bis, incluimos en este concepto la detención que se decreta o practica sin citación previa, con el objeto de asegurar la comparecencia a la audiencia en que se pretende formular verbalmente un requerimiento en juicio simplificado.

Come se ve, la detención imputativa, según la define la doctrina, tiene una finalidad cautelar muy clara: asegurar comparecencia; y tiene otra, más bien discutible, cual es asegurar la adopción de una medida cautelar de mayor intensidad ${ }^{47}$. Esta última

afectando garantías que la ley y el ordenamiento jurídico reconocen al imputado, sin perjuicio de la calificación que alguna otra autoridad judicial pueda decidir al respecto. J.G., Isla de Pascua, 27/01/04, RIT 024. Aparece íntegramente reproducida por HERMOSILLA (F.) y CERDA (R.), en Repertorio de Jurisprudencia del Código Procesal Penal, Primera Edición, ed. La Aurora Ltda., 2004, pp. 105 y ss.

46 LOPEZ, cit., p.364.

47 Usualmente la relación entre detención y prisión preventiva se estudia como una suerte de progresión continua o en cascada de la afectación de la libertad personal, en diversos estadios que se van intensificando, sin solución de continuidad. Así, la detención se presenta como funcional, o a la prisión preventiva, o a las otras medidas de mayor intensidad, las que serán eventualmente decretadas en contra del detenido y que en gran medida justificarían ese estado previo de la detención. Así LOPEZ (J.) cit., p. 365, al definir tanto la detención judicial imputativa como la detención particular o policial en caso de flagrancia, señala que tendrán como objeto asegurar la presencia del imputado a la audiencia de formalización y, eventualmente, adoptar alguna medida cautelar personal de mayor intensidad en su contra. En el mismo sentido, con mayor énfasis, MARIN (J.C.), cit., p. 26, señala que en Chile es perfectamente sostenible una concepción amplia y relativa de la instrumentalidad respecto de otra medida cautelar por aplicación específica del principio de necesidad que, de conformidad con lo dispuesto en el inc. $1^{\circ}$ del art. 122, consagra una subordinación general de las medidas cautelares respecto de los fines del procedimiento, permitiendo una instrumentalidad en cascada: la detención respecto de la prisión preventiva (o de otra medida cautelar personal) y esta respecto de la sentencia definitiva. 
finalidad específica lleva a algunos a denominarla como medida precautelar ${ }^{48}$, en cuanto sería funcional a la futura prisión provisional o preventiva ${ }^{49}$.

Sin dudar de la naturaleza cautelar que tiene la detención imputativa, en cuanto pretende asegurar comparencia, incluso si atendiéramos a su función precautelar $^{50}$, nos parece más relevante detenernos en la finalidad o funcionalidad específica que tiene desde el punto de vista de la vinculación jurídica del imputado con el proceso. No poner este acento es aceptar que las medidas cautelares no están subordinadas al proceso, como método de solución de un conflicto penal, sino que es éste el que debe subordinarse a las primeras.

En la primera audiencia judicial del detenido, como la denomina el art. 132 CPP, cuya celebración asegura la detención, lo que se persigue es provocar la imputación forma $\tilde{P}^{1}$, es decir la formulación de cargos o formalización de la investigación. Sin

\footnotetext{
${ }^{48}$ Se dice que la detención no es instrumental respecto de la sentencia, pero si respecto de la prisión provisional, en cuanto asegura la posibilidad práctica de que ésta se adopte, durante el breve periodo de tiempo que es necesario para constatar si concurren sus presupuestos y en consecuencia, por tener esta característica de instrumentalidad "en segundo plano", se considera a la detención como una medida precautelar. En MARIN (J.C.), cit., p. 25, citando a ORTELLS, que a su turno sigue a DE LUCA.

49 Opinión diversa sostiene DE HOYOS (M.), al menos respecto de la detención por particulares, al señalar que no es la antesala de la prisión provisional (ya que) faltaría instrumentalidad directa, pues la detención no asegura de forma inmediata la prisión provisional, ya que sus presupuestos son distintos (op. cit., p. 101) aunque esa finalidad si la advierte en algunos casos excepcionales de detención policial (p. 226).

50 Puede ser o no cierto que la detención sea un instrumento de otra medida cautelar de mayor intensidad, lo que en verdad la transformaría en una "cautela de la cautela", sin embargo me atrevo a sostener que lo previo o preliminar que tiene la detención no es en relación a otra cautelar, sino que respecto de la iniciación del proceso para el imputado es decir, la iniciación del proceso con el imputado emplazado o formalmente noticiado de su incoación. Entonces no se trataría tanto de una medida precautelar como de una medida cautelar prejudicial. Cuando hablamos de prejudicial, estamos haciendo una traslación del concepto civil de la prejudicialidad, es decir, la cautela previa a la demanda que, en el proceso penal, sería previa a la formalización. Esta prejudicialidad es el rasgo que distingue a la detención como medida cautelar, incluso a la detención por orden del juez y por ello su análisis debe tener muy en cuenta esta perspectiva, especialmente a la hora controlar su legalidad y decidir sobre sus efectos.

${ }^{51}$ La acepción imputación tiene muchos sentidos, sin duda se trata de un acto más o menos formal de atribución de culpa, acción o delito, siguiendo la definición de la Real Academia Española (RAE). Desde el punto de vista procesal, en España, se hace una distinción en el concepto de imputación. Por un lado está la imputación en sentido lato, amplio o genérico que supone la atribución más o menos fundada, a una persona de un acto presuntamente punible sin que haya de seguirse necesariamente acusación contra ella como su consecuencia. Esta imputación se produce desde que se lleve a cabo cualquier actuación procesal contra el imputado implicándole un acto delictivo, incluso desde que haya sido objeto de detención, de acuerdo con el artículo 118 de la Ley de Enjuiciamiento Criminal española (LECRIM). Se debe distinguir de la imputación formal que consiste en la clara incriminación de participación y responsabilidad en un hecho punible, que consiste en un acto judicial garantizador de que el ius puniendi sólo entrará en juego existiendo indicios racionalmente suficientes y que se configura como requisito de procesabilidad, siendo su modalidad más representativa el "procesamiento". MONTERO (J.), GOMEZ (J.), MONTON (A.) y
} 
Arias - El control jurisdiccional de la detención.

duda que lo que se busca con la detención imputativa -y su nombre es sugestivo de aquello- es una comparecencia compulsiva o coercitiva a la formalización de cargos y esa es su función procesal principal, sea que le denominemos función cautelar o no.

Su finalidad última es la de obtener un emplazamiento forzado. Como se trata de vincular jurídicamente al imputado con el proceso y esto se hace compulsiva o coercitivamente, diremos que se trata de un emplazamiento forzado, pese a la contradicción en los términos que en cierto sentido envuelve esta idea. Lo que nos interesa es precisamente realzar las implicancias procesales que la detención imputativa tiene en el sistema de persecución, sin perder de vista que estamos ante un proceso penal al cual debe estar subordinada la detención como categoría conceptual.

En términos muy generales, en derecho procesal, el emplazamiento supone un acto de conminación para comparecer, dentro de un lapso suficiente, a un acto en el cual le corresponde ejercer algún derecho o facultad al emplazado ${ }^{52}$. Lo que ocurre con la detención imputativa es que el ministerio público estará interesado precisamente en emplazar porque normalmente la comunicación de la imputación es una carga procesal para el fiscal que quiere obtener determinadas decisiones a su favor $^{53}$ o sencillamente quiere iniciar la investigación formalizada como requisito ineludible para los pasos sucesivos que permiten, al final del procedimiento, llevar el caso a juicio ${ }^{54}$.

Lo normal será que el imputado sea emplazado mediante citación para comparecer a la audiencia de imputación formal. El art. $231 \mathrm{CPP}$ señala que si el fiscal deseare formalizar la investigación (...) solicitará al juez de garantía la realización de una

BARONA (S.), Derecho Jurisdiccional, T. III, 10a. edición, ed. Tirant lo Blanche, Valencia, 2001, pp. 211 y ss. Consideramos que estas categorías corresponden en Chile, respectivamente, al art. $7^{\circ}$ $\mathrm{CPP}$, como imputación en sentido lato y a la formalización de la investigación, art. $229 \mathrm{CPP}$, como imputación en sentido formal. Además del art. $7^{\circ} \mathrm{CPP}$ por cierto existen otras instancias de imputación en sentido lato, como es el caso de los arts. 94 letra a) y 194 inciso primero CPP.

52 Se define emplazamiento como el acto por el cual el juez fija un espacio de tiempo para la ejecución de una acto procesal (v.gr. se emplaza al demandado para que comparezca a tomar intervención en los autos; se emplaza a uno de los litigantes para que exhiba un documento). DE SANTO (V.), Diccionario de Derecho Procesal, ed. Universidad, Buenos Aires, 1995, p. 121. El emplazamiento es genéricamente definido como el acto procesal en virtud del cual se comunica a una parte a o a un tercero el plazo durante el cual podrá ejercitar un derecho ante el titular del órgano jurisdiccional. FENECH, citado por CAROCCA (A.), Garantía Constitucional de la Defensa Procesal, ed. J.M. Bosch, Barcelona, 1998, p. 230.

${ }^{53}$ Cuando el inciso segundo del art. 230 CPP señala que el fiscal estará obligado a formalizar si quiere obtener determinadas decisiones jurisdiccionales, lo que está señalando es que en tales eventos la formalización es una carga procesal.

${ }^{54}$ Si se trata de detención judicial imputativa la habrá promovido el fiscal. Si se trata de detención imputativa por razón de flagrancia, de acuerdo con el art. 131 CPP, inciso segundo, el fiscal puede "dejarla sin efecto", es decir una vez practicada tiene la opción de persistir o de "desistirse" de provocar la audiencia para la imputación. 
audiencia (a la cual) se citará al imputado, a su defensor y a los demás intervinientes en el procedimiento.

Afirmamos que es lo normal, ya que este precepto se refiere al imputado que no se encontrare en el caso previsto en el artículo 132, es decir, que no se encuentre detenido y lo normal es que las personas no se encuentren detenidas.

Con esto pretendemos señalar que la regla general será la citación para una audiencia de formalización, salvo que estemos en presencia de una detención imputativa. El carácter excepcional de las medidas cautelares y, por cierto de la detención, nos permite afirmar que la citación constituye la regla y la detención su excepción ${ }^{55}$.

Aún si no se quiere ver una relación de regla-excepción entre los arts. 231 y $132 \mathrm{CPP}$, al menos debe quedar claramente establecido que existen dos formas de ingreso al sistema de persecución claramente diferenciadas, que buscan generar la imputación formal, una compulsiva y la otra no. Las dos formas de ingreso están regladas y deben cumplirse estrictamente sus formalidades, para que no se pueda decir que la imputación formal se ha generado con vicios.

El eje de la primera audiencia es la imputación formal, a la cual acceden, como cuestión derivada, no solo las otras medidas cautelares de mayor intensidad $d^{56}$, sino que las restantes materias de discusión, como por ejemplo la determinación de un plazo judicial de cierre de investigación u otras decisiones judiciales que no pueden explicarse por sí mismas, sin la previa comunicación formal de que el proceso penal ya ha sido incoado.

Esta misma finalidad, principalísima, se advierte con mucha claridad en el art. 393 bis CPP, en que el fiscal puede disponer que el imputado sea puesto a disposición del juez de garantía, para el efecto de comunicarle en la audiencia de control de la detención, de forma verbal, el requerimiento.

Aunque el art. 132 CPP, bien leído, lleva a la misma conclusión. El fiscal procederá directamente a formalizar la investigación y, en caso que ello no fuere posible, se

\footnotetext{
55 Si bien no se hace necesaria una declaración legal expresa en este sentido podemos señalar que esta regla igualmente se deduce del art. $231 \mathrm{CPP}$, en particular respecto de la citación para formalización y, en general, de la lectura sistemática de los arts. 33 y $123 \mathrm{CPP}$, en relación con el principio general expresado en el 122 CPP. La citación es la regla para la preparación de juicio (art. 260 CPP) y también para el acto de juicio (art. 281 inc. final CPP y 390 inc. $1^{\circ}$ CPP). En España, el art. 486 LECRIM contiene una norma expresa que señala: La persona a quien se impute un acto punible deberá ser citada sólo para ser oída, a no ser que la ley disponga lo contrario, o que desde luego proceda su detención. 56 Sin duda que desde la perspectiva puramente material o fáctica, las cautelares son el principal interés que puede llegar a tener la primera audiencia. Bastaría con encuestar al imputado cuánto le interesa su derecho a la imputación formal y cuánto la discusión sobre ese accesorio asunto sobre las medidas cautelares. Pero estamos analizando el fenómeno procesal.
} 
Arias - El control jurisdiccional de la detención.

puede conceder una ampliación de la detención con el fin de preparar su presentación, es decir la formalización.

Si la detención imputativa tiene como finalidad principal obtener el emplazamiento forzado, los supuestos de ese "emplazamiento" deben ser válidos para que esa comunicación por la fuerza pueda tener lugar.

\section{Control de la detención no imputativa}

Siendo claro que el control de la detención, en audiencia contradictoria, se aplica a las hipótesis de detención imputativa, podría generarse alguna duda sobre su aplicación a los restantes tipos de detención. Una identificación de la audiencia de control con la primera audiencia de formalización, que es el ámbito que regula el art. $132 \mathrm{CPP}$, podría generar este error.

Obviamente nos referimos al control en audiencia ya que igualmente existen otros mecanismos, que son previos a la ejecución de la detención y, por lo mismo, menos intensivos. Así, por ejemplo, al disponer una orden de aprehensión, será un juez quien habrá ponderado los antecedentes para librarla, pero ese control ha tenido las limitaciones propias de esta decisión generada sin audiencia bilateral, tal como se ha destacado más arriba, además de resultar insuficiente para prevenir la ejecución conforme a derecho del decreto que la dispone.

No es discutido que proceda una audiencia de control en caso que se practique una detención por incomparecencia a una audiencia distinta de la primera audiencia de formalización o requerimiento ${ }^{57}$.

Del mismo modo, es una práctica judicial más o menos extendida, controlar en general toda detención, aunque no se trate de la primera audiencia de formalización o requerimiento, sino que también en casos de detención para asegurar comparecencia al juicio oral o a la audiencia de preparación de juicio, así como la detención para fines de extradición ${ }^{58}$.

Por otra parte, los casos de quebrantamiento de condena y la situación de fuga, no obstante que están relacionados más bien con la ejecución penal que con el aseguramiento de la comparencia, igualmente exigen control en audiencia, no

\footnotetext{
${ }^{57}$ En Litigación Estratégica..., VV.AA., cit., p. 43, se considera expresamente el control también para el caso de la detención como medida cautelar no imputativa, es decir, aquella que se ha decretado por inasistencia injustificada del imputado a cualquier audiencia en la cual su presencia sea requisito de validez (se trate o no de una audiencia de formalización o requerimiento). Parece ser que es el mismo ámbito de aplicación general que describe CHAHUAN (S.), cit., pp. 225 y ss.

58 Por ejemplo, en causa Rol Corte Suprema N ${ }^{\circ} 4479$, sobre extradición pasiva, se dispuso por el Ministro Instructor Sr. Milton Juica Arancibia, realizar una audiencia de control de la detención decretada para fines de extradición.
} 
solo por las razones que hemos descrito y que, en términos generales lo justifican, sino que además por existir norma que avala esta exigencia. En efecto el inciso segundo del art. $131 \mathrm{CPP}$, ordena la puesta a disposición del tribunal "cuando la detención se practicare en virtud de los artículos 129 y 130", es decir, incluyendo estas detenciones y no sólo las hipótesis de flagrancia y detención judicial imputativa. Lo mismo ocurre con la persona que tenga orden de detención pendiente o fuere sorprendida en quebrantamiento flagrante de una medida cautelar o de la condición de la letra b) del art. 238 CPP sobre suspensión condicional del procedimiento ${ }^{59}$.

Desde luego las normas que regulan la detención, y por lo tanto su control, aparecen entre las Disposiciones Generales del Libro Primero del CPP. Por su ubicación y consagración con carácter de normas generales pueden aplicarse a cualquier tipo de privación transitoria y breve de la libertad que no tenga un procedimiento especialmente previsto para su control. Por precaria que sea la reglamentación de la audiencia de control de la detención, como se destacó al inicio, las normas que sirven para construir el sistema de control son de aplicación general, como es el caso de los arts. 94 c), 95 y 131 CPP, además de los arts. 7.5 y 7.6 de la CADH y 9.3 y 9.4 del PIDCP.

La garantía de la libertad personal y seguridad individual, en los términos que se explicaron, está consagrada mediante la exigencia de que el detenido sea puesto a disposición del tribunal que libró la orden ${ }^{60}$, sin distinguir si se trata de un juez de garantía, de un tribunal oral o un ministro de corte en la sustanciación de una extradición pasiva.

Obviamente, así como la detención cumplirá finalidades bien específicas, según sea su especie, también su control jurisdiccional puede tener particularidades o centros de atención más especializados. Así, por ejemplo, si se tratara de la aprehensión para la ejecución de la sentencia, al menos debería determinarse en qué condiciones fue practicada. Pero no sólo la legalidad de su ejecución puede ser relevante. Aquí el control puede cobrar mucha importancia, entre otros asuntos, por la posibilidad que una orden sea tan antigua como para suponer que la pena se

\footnotetext{
${ }^{59} \mathrm{La}$ inclusión de orden de detención pendiente y el quebrantamiento de cautelares o condiciones de una suspensión condicional fueron agregados al art. 129 CPP, dentro de los casos en que la policía debe detener, corresponde a la modificación de la ley 20.074 de 14 de noviembre de 2005.Si la detención se practica por la policía, de acuerdo a su propia versión de una situación de incumplimiento, ello no significa que el juez en definitiva ratificará esta constatación preliminar. La audiencia de control, en este caso, abrirá un interesante campo de discusión sobre el concepto de "flagrancia de quebrantamiento" que introduce la modificación.

${ }^{60}$ Como ya se advirtió, la Ley No 20.074 de 14 de Noviembre de 2005, modificó el art. 70 CPP que regula una excepción, facultando al juez de garantía del lugar donde se practica la detención para controlarla.
} 
Arias - El control jurisdiccional de la detención.

encuentra prescrita y, por cierto, para verificar la identidad del aprehendido, que por lo demás será una meta de todo control de detención ${ }^{61}$.

En definitiva, sostenemos que toda detención está sometida a control en audiencia, cualquiera sea su especie. No se necesita más regulación legal que la que tenemos para fortalecer un adecuado sistema de control de la detención como garantía de la libertad personal y seguridad individual.

Decidir en sentido contrario, dejando lagunas en el control jurisdiccional del ejercicio de fuerza, es dejar que la policía o el ministerio público, decidan en ciertos casos la legalidad de una determinada privación de libertad, generando una suerte de autotutela declarativa sobre el correcto proceder de los órganos de persecución penal. Esto no parece coherente con el nuevo paradigma del sistema de persecución, construido sobre la idea del "no autocontrol", derivado de la división de funciones estatales, tan propio del constitucionalismo clásico ${ }^{62}$.

\section{Efectos de la ilegalidad de la detención}

La ilegalidad de la detención debe tener algún efecto. Si hemos señalado que existe un deber estatal de verificar la legalidad de la detención, lo lógico es que esto trascienda de ser una mera constatación.

La decisión preliminar, en abstracto, de que una detención ha sido ilegal, perfectamente puede ser entendida como una declaración de mera certeza. Esa declaración de certeza puede llegar a tener o no una consecuencia posterior y más específica, normalmente una sanción de ineficacia procesal.

Esta idea tiene que ver con que el proceso es una institución dinámica y no estática. La declaración de mera certeza puede servir de base para el pronunciamiento de otra decisión que, a la postre, produzca efectos procesales constitutivos de derechos, como podría ser una exclusión probatoria o sencillamente una decisión de inutilizabilidad. Lo que ocurre es que la etapa de discusión sobre exclusiones puede llegar a no verificarse nunca o que una petición con fundamento en material probatorio inutilizable puede jamás llegar a plantearse $^{63}$, precisamente por el carácter dinámico del proceso ${ }^{64}$.

\footnotetext{
${ }^{61}$ ROXIN (C.), señala que el requerimiento de captura, si bien tiene como presupuesto normal la orden de detención, también se aplica en el procedimiento de ejecución y considera que la persona aprehendida en virtud de requerimiento de captura debe ser conducida ante el juez. competente, cobrando especial relevancia la comprobación de la vigencia del requerimiento y la identidad de la persona, al punto que ese examen puede hacerlo aún el juez que siendo incompetente debe controlar la detención. Derecho Procesal Penal, Editores del Puerto, Buenos Aires, 2001, pp. 287 y ss.

${ }^{62}$ HORVITZ (Ma . I.), cit., p.447.

${ }^{63}$ Un ejemplo muy concreto lo podemos observar en audiencia del J.G. de Santa Cruz, de 29 de Julio de 2004, RIT 532-2004, la defensa solicita la ilegalidad en atención a que habían transcurrido seis horas entre el hecho imputado y la detención, lo que no constituye en su concepto flagrancia.
} 
REJ - Revista de Estudios de la Justicia - Nº 6 - Año 2005

Además, no toda detención ilegal puede producir el mismo efecto, porque no toda detención persigue la misma finalidad, ni todo control persigue los mismos objetivos.

Por ello parece muy difícil decidir, a priori, si el resultado de una detención ilegal impide per se ampliar la detención o formalizar, o si modifica los estándares para decretar una prisión preventiva, haciéndolos más exigentes, o cualquier otra regla de prohibición o de permisión absoluta que no contemple el análisis parsimonioso de la conexión que se advierta, en concreto, entre la ilegalidad y el paso sucesivo en el proceso.

El Tribunal resuelve declarar ilegal la detención en atención a que si el Ministerio Público o Carabineros sabia la identidad del imputado, debió baber solicitado la orden judicial respectiva que autorizara la detención del mismo, el hecho que el ingreso al domicilio se haya autorizado por el dueño del inmueble, no significa que Carabineros este facultado para detener a las personas que alli se encuentran. La flagrancia es una figura por medio de la cual la policía sabe y le consta de una manera directa y fehaciente que el imputado participó en la comisión del ilícito, cuestión que en la especie no existia porque lo único que habia eran los dichos de los afectados en circunstancias que el imputado ya se encontraba en su domicilio y Carabineros no podía temer por su fuga u ocultamiento. La defensa sostiene que habiéndose declarado ilegal la detención, de acuerdo a lo que establece el Art. 231 del Código Procesal Penal, lo que corresponde es que el Ministerio Público solicite una audiencia para formalizar, por cuanto la presencia de (su) defendido en este Tribunal es ilegal, él no fue citado ni detenido en flagrancia. El Fiscal: no me opongo y estoy llano a que se fije otra audiencia para efectos de formalizar debidamente.

${ }^{64}$ Cuestión completamente distinta es que una decisión de ilegalidad, asumida como tal y a la cual le habíamos asignado ciertas consecuencias jurídicas, en la realidad del proceso no produzca el alcance conceptualmente asignado. Veamos algunos ejemplos: Así, en audiencia del J.G. de Coyhaique, de 14 de Enero de 2003, RIT 18-2003, el tribunal acoge el incidente de ilegalidad planteado por la defensa, fundado en que no se había dado a conocer el motivo de la detención. En consecuencia declara ilegal la detención y decreta la inmediata libertad en relación con las amenazas a particular, en relación con el imputado SAFR, sin perjuicio de ello, y atendido lo que ha señalado el Fiscal, en orden a que existe un segundo delito, el Tribunal emitirá pronunciamiento después de darle el curso regular a la audiencia, en relación con la incompetencia señalada, respecto del delito causado a funcionario público, en este caso para los efectos de requerir la intervención del Tribunal competente, la Fiscalía Militar (...) previo debate sobre la procedencia o no del requerimiento sobre el cual la Defensoría se opone, el Juez le otorga la palabra al Fiscal para que formalice o requiera, pues se trata de una audiencia de Control de la Detención, y estamos en la hipótesis del artículo 393 bis del Código Procesal Penal, lo que hace procedente cualquiera de estas actuaciones por el Fiscal. De la misma manera, en audiencia del J.G. de San Fernando, 3 de Julio de 2004, RIT 838-2004, la defensa alega la ilegalidad de la detención del imputado MHC por cuanto lo fue por un delito de manejo en estado de ebriedad... (en circunstancias que)...de acuerdo a lo dispuesto en el artículo 189 del de la Ley 18.290 dicho delito amerita solo una medida cautelar de citación y no una detención. El tribunal declara ilegal la detención en éste caso y se da orden de libertad a favor del imputado, sin perjuicio de ello el Tribunal no va hacer ninguna otro tipo de actuación al respecto. La Defensa solicita que se ponga término a la audiencia. El Fiscal consulta al Tribunal si la libertad inmediata imposibilita realizar alguna actuación. El Tribunal ya resolvió ese punto en audiencia anterior y estima que efectivamente si el Ministerio Público desea realizar otra actuación atendido que el imputado se encuentra presente en la audiencia y para no efectuar dilaciones innecesarias y que vuelva ha comparecer podrá realizarse en la misma audiencia. Por último, en audiencia ya citada, luego de constatar que la detención "se practicó sin cumplir con los requisitos legales", el defensor solicita la inmediata libertad de su representado y el tribunal resuelve: Atendido lo declarado, el Tribunal dispone la inmediata libertad de DGZB, sin perjuicio de que debe permanecer en la audiencia, dado que el tribunal tiene noticia que el Sr. Fiscal va a formular un requerimiento en su contra. J.G., Isla de Pascua, 27/01/04, RIT 024. HERMOSILLA (F.) y CERDA (R.), cit., pp. 105 y ss. 
Arias - El control jurisdiccional de la detención.

En esta oportunidad sólo intentaremos sistematizar estos posibles efectos que, dentro del proceso, dicen relación con sanciones de ineficacia procesal con base en la ilegalidad previamente constatada.

Cuando estamos en presencia de la imposibilidad de seguir adelante con el proceso por un emplazamiento forzado provocado irregularmente, en el fondo las pretensiones se hacen inadmisibles, lo que constituye una sanción de ineficacia. Cuando estamos hablando de la inutilizabilidad, estamos hablando de una sanción procesal de ineficacia probatoria.

\subsection{Efectos respecto del proceso}

\section{1.a) Ineficacia del emplazamiento forzado}

Por las razones que se explicaron más arriba, en aquellos casos que la ilegalidad diga relación con la detención imputativa, parece lógico esperar que el resultado sea la ineficacia de lo que hemos denominado emplazamiento forzado. Entonces no podrá satisfacerse el fin último que perseguía la detención y por lo tanto no podrá procederse a la formalización, ni al requerimiento en su caso.

Naturalmente, en ello no hay impedimento para que el imputado, debidamente asesorado, acepte seguir adelante con la etapa siguiente y escuchar la formalización o requerimiento ya que en este caso la voluntad del imputado juega un $\mathrm{rol}^{65}$. Existiendo aquiescencia del detenido no se divisa un obstáculo para seguir con el curso del procedimiento.

Esta renuncia parece inadmisible si la ilegalidad dice relación con el uso de métodos prohibidos, ya que en tal caso el consentimiento resulta irrelevante, de acuerdo con la regla del art. 195. inciso final, CPP.

Por similares razones no parece admisible, en estos casos, permitir la ampliación de la detención. La prolongación de una detención se justifica en cuanto se quiere preparar una presentación que es específicamente la formalización.

Aquí se estaría prolongando el estado de detención con la misma finalidad de provocar la imputación formal. La detención es la misma, lo que permite la norma es ampliar su extensión en el tiempo. Desde luego esta posibilidad, en el art. 132, inciso segundo CPP, está concebida como una "ampliación del plazo de

\footnotetext{
${ }^{65}$ Será una renuncia a reclamar sobre los supuestos del emplazamiento forzado. Y está demostrado que el consentimiento juega un rol frente al emplazamiento ya que si la formalización puede ser incluso provocada por el propio imputado, ante la jactancia del ministerio público (art. $186 \mathrm{CPP}$ ), con mayor razón podrá renunciarse a los efectos de ineficacia del emplazamiento forzado para los mismos efectos: la comunicación de la imputación.
} 
detención hasta por tres días", es decir una extensión de las veinticuatro horas legales. La ampliación no es una cautelar distinta de la detención que ya se libró o practicó $^{66}$. Luego, no se entiende cómo el juez podría hacer una nueva ponderación de los mismos antecedentes que la generaron y que llevaron a decir que era ilegal, esta vez para extender sus efectos, más allá del plazo de veinticuatro horas inicial.

Para fundar la improcedencia de seguir adelante con esta primera audiencia, en la cual se ha declarado ilegal la detención, se sostiene que, una vez declarada la ilegalidad, ya no se está en el supuesto del art. 132 CPP que comprende un caso de detención legal. Entonces se debería aplicar el art. $231 \mathrm{CPP}$, que regula la situación "no prevista en el artículo 132". Nos parece relevante este argumento de texto, al tenor de lo que disponen los preceptos citados, pero su sola consideración literal resulta insuficiente, si no se presta atención a la cuestión del emplazamiento en forma.

Si el argumento es que el art. 231 CPP sólo permite fijar una audiencia para la formalización en fecha próxima y sólo eso, entonces la economía procesal podría cobrar algún sentido para continuar con la audiencia ya que, estando presente el detenido, no haría sentido esperar esa fecha próxima si se puede adelantar esa audiencia y despejar la agenda del tribunal. El punto es que estos preceptos regulan dos formas de emplazamiento cuyos supuestos legales deben cumplirse estrictamente.

A todas estas consideraciones debe agregarse el respeto por el derecho a la defensa material. El emplazamiento debe contemplar algún lapso, para que el emplazado reaccione procesalmente, en este caso para permitir preparar adecuadamente y con tiempo suficiente la defensa, especialmente ante las eventuales consecuencias adversas que trae aparejada la incoación del proceso ${ }^{67}$. Entonces la economía procesal también queda desplazada ya que no se entendería un sacrificio del derecho a la defensa por razones de esta naturaleza ${ }^{68}$.

\footnotetext{
${ }^{66}$ En general no se le considera como una medida cautelar distinta sino que como una ampliación del plazo. Así LOPEZ (J.), cit., p. 383, señala que el plazo para poner al detenido a disposición del tribunal no es ampliable. Sin embargo, una vez puesto el imputado a disposición del tribunal el fiscal puede solicitar una ampliación de la detención hasta por tres días. En el mismo sentido MARIN (J.C.), cit., p. 28, que no trata la ampliación de la detención como una medida cautelar distinta sino como una variante del plazo de detención, concluyendo que en el evento de una detención judicial la regla general es que ella dure veinticuatro horas pudiendo, excepcionalmente, alcanzar un plazo máximo de cuatro días. Igualmente CAROCCA (A.), Manual. El nuevo sistema procesal penal, ed. Lexis Nexis, Santiago, 2005, pp. 159 y ss., especialmente p. 165 en que, respecto la detención por flagrancia, considera que el fiscal puede solicitar al juez de garantía una audiencia para pedir la prolongación de la detención basta por otros tres días, o bien formalizar la investigación.

${ }^{67} \mathrm{Vid}$. Supra nota 31, especialmente la referencia al ejercicio del derecho a la defensa.

${ }^{68}$ No se entendería cómo, en nuestro nuevo sistema acusatorio, pudo concebirse una regla general que consiste en que la incoación del proceso se noticie aceleradamente, con fines de acotar lo más posible la posibilidad de reacción procesal, minimizando el tiempo de respuesta defensiva.
} 
Arias - El control jurisdiccional de la detención.

\section{1.b) Ineficacia del material probatorio}

Existe solución de texto para el caso que la detención ilegal haya dado lugar a la obtención de material probatorio. Si se llega a la etapa de preparación de juicio, regirá la regla de exclusión probatoria contemplada en el art. 276 CPP.

El problema se presenta en la etapa de investigación ya que no existe solución legal expresa. No obstante ello, se sostiene que aún en la etapa de investigación se puede considerar la ineficacia de la prueba ilícita, sea en términos restringidos, respecto de la justificación de medidas cautelares ${ }^{69}$, sea en términos amplios extendiendo esta regla también a las medidas intrusivas, bajo el concepto de inutilizabilidad ${ }^{0}$. Esta última solución es la que suscribimos ${ }^{71}$.

Las razones que, entre nosotros, se han dado para justificar esta "anticipación” de la regla de exclusión son principalmente las siguientes: Se argumenta que si la aplicación de una medida cautelar supone un pronóstico fundado de condena entonces, la consideración de la ilicitud de prueba en sede de cautelares, del mismo modo, se justifica por un pronóstico de absolución fundado en esa circunstancia, a lo que se debe agregar el déficit de legitimación que informa el fundamento ético de la exclusión ${ }^{72}$. También se ha dicho que es un absurdo sistemático permitir el uso de prueba ilícita en investigación y no en el juicio, generando prácticamente dos investigaciones paralelas, una en que prácticamente estaría todo permitido y otra en la que se respetan los derechos fundamentales y, asimismo, que no resulta admisible la coerción en el proceso, que es sacrificio de derechos fundamentales, a costa de otra afectación de derechos fundamentales ${ }^{73}$.

A todo lo dicho sólo podríamos agregar alguna razón de texto. En materia de cautelares, lo que exige el art. 140 letra a) CPP es que el solicitante de la prisión preventiva, por extensión de las medidas del art. $155 \mathrm{CPP}$, acredite que se encuentra justificada la existencia del delito ${ }^{74}$. No puede haber tal justificación si esta se basa en un procedimiento contrario a derecho, ilegal.

\footnotetext{
${ }^{69}$ HERNANDEZ (H.), La exclusión de la prueba ilícita en el nuevo proceso penal chileno, Colección de Investigaciones Jurídicas, $N^{\circ}$ 2, Universidad Alberto Hurtado, 2004, pp. 88 y 89.

${ }^{70}$ LOPEZ (J.), cit., T. II, pp. 204 y ss.

${ }^{71}$ Como señala CAFFERATA NORES, aunque no bubiera reglamentación expresa, la tutela de las garantías individuales constitucionalmente reconocidas, exigirá que cualquier dato probatorio que se obtenga en violación de ellas, sea considerado ilegal y, por ende, carezca de valor para fundar la convicción del juez. Para eso están las garantias. Cita de HAIRABEDIAN (M.), en Eficacia de la prueba ilíita y sus derivadas en el proceso penal, AD-HOC, Buenos Aires, 2002, p. 57.

72 HERNANDEZ (H.), cit., pp. 88 y 89.

${ }^{73}$ LOPEZ (J.), cit., T. II, pp. 205 y 206.

74 Las tres primeras acepciones de justificar según la RAE son: 1.- Probar algo con razones convincentes, testigos o documentos. 2.- Rectificar o bacer justo algo. 3.- Probar la inocencia de alguien en lo que se le imputa o se presume de él.
} 
No se divisa un fundamento jurídico, ni menos ético, para permitir la incorporación al proceso penal de fuentes de prueba ilícitas si se trata de justificar una resolución sobre medidas cautelares y de rechazar la prueba misma cuando se trata de fundar una sentencia definitiva. Esto sería prohibir su uso directo como medio probatorio, pero tolerar su aprovechamiento indirecto, como fuente de prueba $^{75}$.

El más alto estándar que exige una sentencia condenatoria en relación con las medidas cautelares, es una cuestión que dice relación con la intensidad de la convicción y no con el problema de los límites formales al establecimiento de la verdad. Sea cual sea el estándar que se exija para establecerla, estos límites existen y deben respetarse.

La sola acepción lingüística del vocablo justificar nos remite al concepto de probar o, al menos, hacer justo algo, por lo cual, aún tratándose de una actividad jurisdiccional y un grado de convicción diversos de aquellos que se exigen en etapa propiamente probatoria, su vinculación con las exclusiones es evidente. Si jurídicamente no se puede probar la existencia de un hecho por medios ilícitos, tampoco se le puede justificar con base en los mismos.

\subsection{Efectos respecto del imputado. La libertad como brecha entre la actuación legal y la ilegal}

Pensamos que en los casos graves de ilegalidad debería producirse la libertad del detenido, al menos como consecuencia indirecta. Por ejemplo, en la ejecución de la detención legalmente librada, se pudo incurrir en conductas inequívocamente prohibidas, como la tortura u otros métodos inadmisibles.

En casos como estos, los efectos deben considerarse también respecto del imputado, tomando en cuenta que es el destinatario de la garantía de la libertad personal y seguridad individual. El quebrantamiento del derecho, en casos tan graves, no puede dejar indiferente al sistema. El restablecimiento del derecho exige una respuesta estatal tan enérgica -"proporcional", si se quiere- como enérgica ha sido la infracción.

La cautela de garantías, contemplada en el art. 10 CPP, entrega amplias facultades para restablecer el imperio del derecho. Si esta norma permite incluso suspender el procedimiento para evitar que pueda producirse una afectación sustancial de los derechos del imputado, con mayor razón se puede suspender la audiencia que debió tener lugar o, eventualmente, postergar la etapa del procedimiento a la que acceda

\footnotetext{
${ }^{75}$ El Tribunal Supremo Español, aceptando el fundamento disuasorio de las reglas de exclusión ha sostenido que probibir el uso directo de estos medios probatorios y tolerar su aprovechamiento indirecto constituiría una proclamación vacía de contendido efectivo - se refiere a la consagración de derechos fundamentales- $e$ incluso una incitación a la utilización de procedimientos inconstitucionales que, indirectamente, surtirán efectos (el destacado es nuestro). Sala II, sentencia de 29/3/1990, citada por HAIRABEDIAN (M.), cit., p. 48.
} 
Arias - El control jurisdiccional de la detención.

la detención ilegal. La facultad de ordenar la inmediata libertad del imputado está implícita en esta facultad cautelar ${ }^{76}$.

Pensemos en el uso de métodos prohibidos con efectos físicos o psíquicos evidentes en la persona sometida a control de la detención. Si la prolongación de la detención o el ejercicio de fuerza en la captura o cualquier método prohibido ha provocado tales efectos, es dable suponer que el imputado sometido a detención no está en condiciones de mantenerse en una audiencia donde debe ser oído. En estas hipótesis, por cautela de garantías, se podría producir la libertad del detenido, como consecuencia indirecta.

Sin embargo, nos atrevemos a sostener que esta consecuencia, la liberación del detenido ilegalmente, también se puede producir como consecuencia directa, como resultado del habeas corpus contemplado en el art. 95 CPP o de la aplicación de los arts. 9.4 del PIDCP y 7.6 de la CADH, que contienen cláusula expresa de liberación ante la ilegalidad de la detención.

Ante la constatación de una grave vulneración, el Estado no estará en condiciones de obtener ningún provecho procesal de sus propias conductas ilícitas. Si en verdad existe un fundamento ético en los métodos prohibidos, pareciera ser que la única manera de restablecer el imperio del derecho es generar una brecha entre la ilegalidad y la legalidad. Esa brecha se puede producir impidiendo seguir adelante con la audiencia o, en su caso, eventualmente con el procedimiento.

\subsection{Efectos extra proceso}

Sobre los efectos fuera del proceso, por exceder la materia de este trabajo, sólo haremos su enunciación. Concordamos con lo que en términos generales se ha dicho sobre esta materia. Estos efectos pueden ser: a) Responsabilidad administrativa de los funcionarios que intervienen en el procedimiento ilegal; b) Responsabilidad penal de los funcionarios o particulares que intervienen en el procedimiento ilegal; c) Responsabilidad civil de los funcionarios o particulares que intervienen en el procedimiento ilegal.

Se podría considerar también como un efecto extra proceso el surgimiento del derecho a la acción constitucional de amparo a favor del detenido. En estricto rigor, esta consecuencia no es, necesariamente, derivada de la ilegalidad constatada en el control de la detención. Eventualmente puede nacer del caso inverso, en que

\footnotetext{
$76 \mathrm{Al}$ no estar comprendido el tribunal oral en el art. $10 \mathrm{CPP}$, carecería de esta facultad de suspender el procedimiento. Aunque las facultades de suspensión de la audiencia o del juicio, interpretadas armónicamente en relación con el art. $97 \mathrm{CPP}$, permiten una solución para casos graves. En este sentido, resulta sugestiva la última parte del art. 283 CPP que dispone que la comunicación de la fecha y hora de continuación de la audiencia de juicio se tendrá como suficiente citación, es decir, el acusado, si es del caso, podría quedar citado para la continuación de la audiencia o del juicio, y no mantenerse privado de libertad .
} 
REJ - Revista de Estudios de la Justicia - No 6 - Año 2005

no se constata, precisamente para que la magistratura que señala la ley sancione la ilegalidad que no ha divisado el juez de garantía.

El surgimiento de este derecho lo consideramos como efecto extra proceso, porque se trata de una acción independiente del sistema de control jurisdiccional que hemos analizado ${ }^{77}$. Como se ha dicho para explicar la procedencia del habeas corpus respecto de resoluciones judiciales, se trata de un juicio originario, primigenio, cuyo propósito es precisamente calificar si una conducta se ajusta o no a las normas cautelares de la libertad y de la seguridad y para emitir, como resultado de tal análisis, una decisión jurisdiccional nueva, desconocida en el ámbito del derecho, de manera tal que la resolución que se pronuncia comprende una materia nunca antes vista por una resolución jurisdiccional, lo cual acontece aún si se recurre ante la decisión de un tribunal de privar de libertad a un ciudadano ${ }^{78}$.

\footnotetext{
77 Sólo se debe precisar que se puede reclamar de la ilegalidad de la detención tanto mediante acción constitucional de amparo, como por los medios procesales que contempla el CPP, sin que estas vías sean excluyentes. El art. 95 contempla este amparo "sin perjuicio de lo establecido en el artículo 21 de la Constitución Política de la República", a diferencia de lo que ocurría con el art. 306 del Código de Procedimiento Penal (1906) que concedía acción de amparo "si no se hubiere deducido los otros recursos legales". La jurisprudencia de Corte Suprema ha sido reiterada en este sentido. Así, por ejemplo, sentencia Rol No 4454-05, de 08/09/05, que en lo pertinente señala que el artículo 95 del Código Procesal Penal, que estableció un procedimiento de amparo ante el juez. de garantía, dejó expresamente a salvo -en su inciso final- la posibilidad de intentar la acción constitucional referida. No obsta a lo anterior la norma del articulo 149 del Código Procesal Penal, que permite apelar de las resoluciones que ordenan la prisión preventiva decretadas en una audiencia, desde que no existe disposición alguna que haga incompatible dicho recurso con el referido amparo constitucional. 78 TAVOLARI (R.), Habeas corpus..., cit., p. 93.
} 